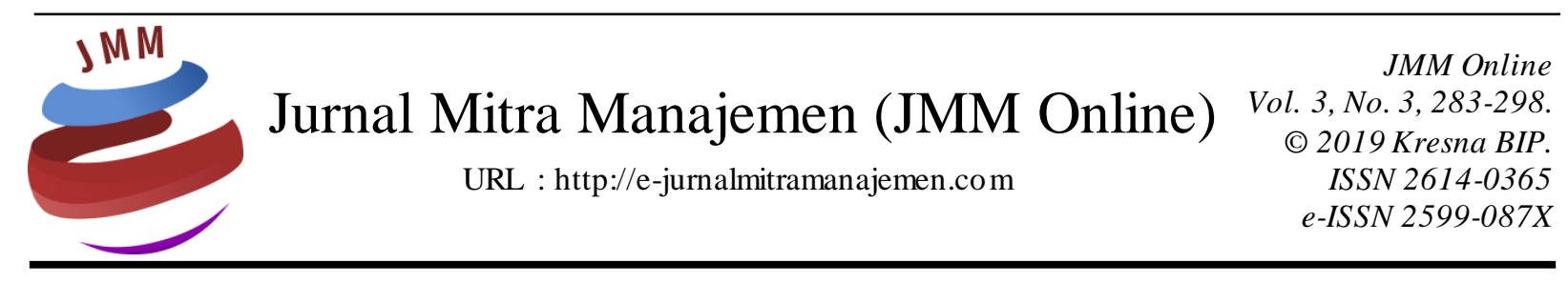

\title{
ANALISIS TREND PENJUALAN DENGAN METODE LEAST SQUARE PADA APOTEK SWASTA SURABAYA
}

\author{
Intan Kurnia Permatasari \\ Akademi Farmasi Surabaya
}

INFORMASI ARTIKEL

Dikirim : 28 Februari 2019

Revisi pertama : 26 Maret 2019

Diterima : 27 Maret 2019

Tersedia online : 28 Maret 2019

Kata Kunci: Penjualan, Trend Analysis, Least Square

Email : intan.nia18@gmail.com

\begin{abstract}
ABSTRAK
\end{abstract}
Pengelolaan menejemen keuangan pada salah satu Apotek Swasta di Surabaya belum berjalan dengan baik sehingga untuk melihat fluktuasi hasil penjualan tidak diketahui secara pasti. Tujuan penelitian ini untuk menganalisis penjualan obat dan alat kesehatan di salah satu Apotek Swasta Surabaya pada periode Januari 2017 sampai dengan April 2018 dengan metode least square. Pengambilan data menggunakan metode dokumentasi berupa laporan penjualan obat dan alat kesehatan deng an teknik pencatatan data dan teknik wawancara berkaitan faktor internal yang mempengaruhi hasil penjualan. Hasil yang diperoleh dari penelitian ini pada kuartal satu nilai trend mengalami kenaikan dengan penjualan tertinggi di bulan Maret 2017. Pada kuartal dua nilai trend mengalami peningkatan dengan penjualan tertinggi di bulan Juni 2017 dan penurunan penjualan di bulan Juli 2017. Pada kuartal tiga mengalami peningkatan nilai trend dengan penjualan tertinggi pada bulan Desember 2017 dan penurunan penjualan di bulan November 2017. Pada kuartal empat nilai trend meningkat, pencapaian nilai trend tertinggi dan hasil penjualan tertinggi di bulan Maret 2018 sedangkan hasil penjualan menurun di bulan April 2018. Faktorfaktor yang mempengaruhi hasil penjualan diantaranya penambahan dan penurunan jumlah pasien, ketersediaan stok obat, keluhan pasien, pelayanan kepada pasien, pengadaan obat, fasilitas, tenaga kerja, dan harga. 


\section{PENDAHULUAN \\ Latar Belakang}

Apotek adalah suatu tempat tertentu yang digunakan untuk melakukan pekerjaan kefarmasian berupa penyaluran perbekalan farmasi kepada masyarakat. Salah satu Apotek Swasta di Surabaya bergerak dalam bidang penjualan obat dan alat kesehatan, baik menggunakan resep ataupun tanpa resep. Apotek Swasta tersebut memiliki beberapa sistem diantaranya persediaan, pembelian, dan penjualan.

Analisis trend adalah suatu metode analisis statistika yang ditujukan untuk melakukan estimasi atau peramalan pada masa yang akan datang untuk melakukan peramalan (Harahap, 2009). Hal ini membutuhkan berbagai macam informasi data yang cukup banyak dan diamati dalam periode waktu yang relatif cukup panjang, sehingga hasil analisis tersebut dapat mengetahui sampai berapa besar fluktuasi yang terjadi. Secara umum analisis trend peramalan anggaran pendapatan mempunyai manfaat sebagai alat pengawas kerja yang membantu menejemen dalam mencapai tujuan perusahaan serta sebagai dasar penyusunan anggaran pendapatan (penjualan), sedangkan metode least square yaitu menentukan persamaan garis yang mempunyai jumlah terkecil dari kuadrat selisih data asli dengan data pada garis trend.

Pengelolaan menejemen keuangan pada Apotek Swasta tersebut belum berjalan dengan baik sehingga untuk melihat fluktuasi hasil penjualan tidak dapat diketahui secara pasti. Salah satu cara menganalisa hasil penjualan dapat menggunakan metode least square karena metode ini paling umum dan sering digunakan untuk menentukan peramalan bisnis karena itu, dengan realisasi yang telah dilakukan, maka perusahaan dapat menilai apakah perusahaan telah bekerja dengan baik atau tidak (Yulfida, 2012). Berdasarkan uraian diatas, maka penulis tertarik untuk meneliti mengenai analisis trend penjualan dengan metode least square pada salah satu Apotek Swasta di Surabaya.

\section{Rumusan Masalah}

Bagaimana analisis trend penjualan dengan metode least square pada salah satu Apotek Swasta Surabaya periode Januari 2017 sampai April 2018.

\section{Tujuan Penelitian}

Untuk menganalisis trend penjualan pada salah satu Apotek Swasta Surabaya periode Januari 2017 sampai April 2018 sebagai informasi dalam pengelolaan manejemen keuangan.

\section{KAJIAN PUSTAKA}

\section{Tinjauan Tentang Pengertian Obat}

Menurut Undang-undang Kesehatan No.36 tahun 2009, obat adalah bahan atau paduan bahan, termasuk produk biologi yang digunakan untuk mempengaruhi atau menyelidiki sistem fisiologi atau keadaan patologi dalam rangka penetapan diagnosi, pencegahan, penyembuhan, pemulihan, peningkatan kesehatan dan kontrasepsi untuk manusia. Penggolongan obat yaitu sebagai berikut: (1) Obat bebas; (2) Obat bebas terbatas; (3) Obat keras; (4) Obat psikotropika; (5) Obat narkotika; (6) Obat wajib apotek. 


\section{Tinjauan Tentang Alat Kesehatan}

Menurut Peraturan Menteri Kesehatan Republik Indonesia Nomor 1190/MENKES/PER/VII/2010, alat kesehatan adalah instrumen, aparatus, mesin dan/atau implan yang tidak mengandung obat yang digunakan untuk mencegah, mendiagnosis, menyembuhkan dan meringankan penyakit, merawat orang sakit, memulihkan kesehatan pada manusia, dan/atau membentuk struktur dan memperbaiki fungsi tubuh.

\section{Forecast Penjualan}

Untuk dapat meramalkan, memperkirakan atau memprediksi sesuatu (nilai suatu variabel) di masa yang akan datang maka perlu adanya data masa lampau. Kualitas dari suatu ramalan, perkiraan atau prediksi sangat berkaitan erat dengan informasi yang dapat diserap dari data masa lampau. Para pelaku ekonomi dan bisnis terutama pengambil keputusan sangat berkepentingan dengan adanya data masa lampau. Data masa lampau ini dipelajari lalu dianalisis, berdasarkan hasil analisis itulah akan memperoleh gambaran mengenai sesuatu (nilai variabel) dimasa yang akan datang. Berdasarkan gambaran yang diperoleh maka dapat diambil keputusan untuk merencanakan suatu kegiatan. Deret waktu/data berkala adalah data yang disusun berdasarkan urutan waktu terjadinya dan menggambarkan perkembangan suatu kejadian atau suatu kegiatan. Data masa lampau ini dapat saja dicatat secara berturutturut dalam interval waktu satu bulan, satu tahun, satu semester, satu kuartal, satu triwulan, harian, dan satuan waktu lainnya. Sedangkan analisa deret waktu/analisa data berkala adalah suatu metode kuantitatif yang mempelajari pola gerakan data masa lampau yang teratur. Jika pola data masa lampau tersebut telah diketahui atau ditemukan maka berdasarkan pola tersebut diharapkan kita dapat mengadakan peramalan dan perencanaan dimasa yang akan datang (Budiasih, 2012).

Analisis trend merupakan suatu metode analisis statistik yang ditunjukan untuk melakukan suatu estimasi atau peramalan pada masa yang akan datang. Analisis trend bertujuan untuk mengetahui kecenderungan keadaan keuangan perusahaan di masa yang akan datang baik kecenderungan naik, kecenderungan turun maupun tetap. Analisis trend ini biasanya digunakan untuk menganalisis keuangan yang meliputi minimal 3 periode atau lebih. Dibutuhkan berbagai macam informasi yang cukup banyak dan diamati dalam periode waktu yang relatif cukup panjang, sehingga hasil analisis tersebut dapat mengetahui besar fluktuasi yang terjadi dan faktor-faktor apa yang mempengaruhi perubahan tersebut (Harahap, 2009). Trend merupakan kecenderungan meningkat atau menurun untuk jangka waktu yang panjang.

\section{Faktor-Faktor yang Mempengaruhi Pendapatan/Penjualan}

Faktor-faktor penyebab turunnya pendapatan secara garis besar dapat dibedakan menjadi dua kelompok (Munandar, 2010), yaitu:

1. Faktor-Faktor Intern

a. Penjualan tahun-tahun yang lalu meliputi kualitas, kualitas harga, waktu maupun tempat (daerah) penjualannya.

b. Kebijakan perusahaan yang berhubungan dengan masalah penjualan, seperti saluran distribusi, promosi, serta cara penetapan harga. 
c. Kapasitas produksi yang dimiliki oleh perusahaan serta memungkinkan perlunasannya diwaktu yang akan datang.

d. Tenaga kerja yang tersedia, baik jumlahnya maupun keterampilan dan keahliannya serta kemungkinan pengembangan diwaktu yang akan datang.

e. Fasilitas-fasilitas yang dimiliki oleh perusahaan serta kemungkinan perlunasannya diwaktu yang akan datang. Sampai batas-batas tertentu, perusahaan masih dapat mengatur dan menyelesaikan faktor-faktor intern dengan apa yang diinginkan untuk dimasa yang akan datang. Sebab ini sering disebut sebagai faktor yang dapat diatur dan diawasi.

2. Faktor-Faktor Ekstern

a. Keadaan persaingan pasar.

b. Posisi perubahan dalam persaingan.

c. Tingkat pertumbuhan penduduk.

d. Tingkat penghasilan masyarakat.

\section{METODE PENELITIAN}

\section{Teknik dan Instrumen Pengumpulan Data}

Instrumen pengumpulan data yaitu cara yang digunakan untuk mengumpulkan data. Metode pengumpulan data yang digunakan dalam penelitian ini dimaksudkan untuk memperoleh informasi yang relevan dan akurat meliputi :

1. Metode dokumentasi

Pengambilan sampel dilakukan dengan sistem dokumentasi yaitu alat pengumpulan data yang berupa dokumen laporan penjualan obat dan alkes pada periode tersebut. Teknik ini dilakukan dengan mencatat data berdasarkan laporan penjualan harian diambil pada periode Januari 2017-April 2018.

2. Metode wawancara

Metode pengumpulan data dengan wawancara merupakan cara yang banyak digunakan oleh para peneliti. Wawancara dilakukan kepada Apoteker, adapun inti pertanyaan yang digunakan dalam wawancara meliputi: 1): Penambahan pasien menyebabkan peningkatan hasil penjualan,; 2). Penurunan pasien menyebabkan penurunan hasil penjualan; 3). Ketersediaan stok dapat mempengaruhi hasil penjualan dan 4). Keluhan pasien dapat mempengaruhi hasil penjualan.

\section{Teknik Pengolahan dan Analisis Data}

Penelitian ini adalah penelitian deskriptif kuantitatif dengan pengambilan data sekunder, diperoleh dari dokumen yang dimiliki oleh Apotek berupa laporan penjualan harian obat dan alkes pada periode Januari 2017-April 2018 dan uraian hasil wawancara. Teknik analisis data yang digunakan dalam penelitian ini menggunakan langkah-langkah sebagai berikut:

1. Pengumpulan data

Pada penelitian ini pengumpulan data dilakukan menggunakan sistem dokumentasi dan wawancara.

2. Laporan penjualan berdasarkan bulan di buat dalam bentuk data

a. Pengolahan data trend hasil penjualan dilakukan dengan program Microsoft excel sebagai berikut. 
Tabel 1. Analisis Least Square

\begin{tabular}{|l|l|l|l|l|}
\hline Skala waktu (Bulan) & Penjualan (Y) & \multicolumn{1}{|c|}{$\mathbf{X}$} & \multicolumn{1}{|c|}{ XY } & $\mathbf{X}^{\mathbf{2}}$ \\
\hline Januari & & -3 & 9 & \\
\hline Februari & & -1 & 1 & \\
\hline Maret & & -1 & 1 & \\
\hline Dst & & 3 & 9 & \\
\hline Jumlah & & 0 & 20 & \\
\hline
\end{tabular}

Sumber : Data Primer (2018)

b. Menentukan persamaan trend yaitu dengan mencari nilai a dan b menggunakan rumus sebagai berikut :

$$
\mathrm{Y}=\mathrm{a}+\mathrm{bX}
$$

Keterangan

$\mathrm{Y} \quad=$ Variabel terikat

a $\quad=$ Intersep Y, merupakan bilangan konstan

$\mathrm{b} \quad=$ Slope garis trend

$\mathrm{X} \quad=$ Variabel bebas

Untuk melakukan perhitungan analisa trend menggunakan metode least square, maka diperlukan nilai tertentu pada variabel waktu $(\mathrm{x})$ sehingga jumlah nilai variabel waktu adalah nol atau $\sum x=0$. Dalam menentukan nilai $x$, dibagi menjadi 2 kelompok, yaitu

Data genap, maka nilai $\mathrm{x}$

Data ganjil, maka nilai $\mathrm{x}$

$$
\begin{aligned}
& \ldots-5,-3,-1,1,3,5 \ldots \\
& \ldots-3,-2,-1,0,1,2,3 \ldots
\end{aligned}
$$

c. Menentukan nilai $\mathrm{a}=\sum \mathrm{Y} \mathrm{i} / \mathrm{n}$

d. Menentukan nilai $\mathrm{b}=\sum \mathrm{XiYi} / \sum \mathrm{Xi}^{2}$

3. Menghitung nilai trend menggunakan beberapa periode. Pada penelitian ini diperlukan nilai tertentu pada variabel waktu (x) sehingga jumlah nila variabel waktu adalah nol $\sum \mathrm{x}=0$. Data yang tersedia (n) genap maka jarak antara dua waktu diberi nilai dua satuan, diatas nol diberi tanda negatif dan dibawah nol diberi tanda positif.

4. Kemudian membuat grafik berdasarkan nilai $\mathrm{X}^{2}$ menggunakan bantuan Miscrosoft Excel, bertujuan untuk melihat grafik trend. serta membuat grafik Y bertujuan untuk melihat kenaikan dan penurunan hasil penjualan pada setiap bulan.

5. Setelah diketahui terjadinya peningkatan atau penurunan hasil penjualan, kemudian membandingkan nilai pendapatan dengan nilai trend dan dianalisa faktor-faktor yang mempengaruhinya dilakukan dengan metode wawancara mendalam berdasarkan analisa data objektif yang telah dilakukan pengamatan sebelumnya meliputi jumlah pengunjung, kemampuan nilai beli, dan ketersediaan stok obat dan alkes yang digunakan untuk menggali informasi secara terperinci. Pertanyaan yang diberikan antara lain :

\section{Tempat dan Waktu Penelitian}

Penjualan obat bebas, obat bebas terbatas, obat keras yang terdapat di salah satu Apotek Swasta di Surabaya pada periode Januari 2017-April 2018. 


\section{HASIL PENELITIAN DAN PEMBAHASAN Hasil Penelitian}

Dari hasil penelitian analisa perhitungan menggunakan metode least square dengan 8 pertanyaan yang ditanyakan kepada Apoteker dan TTK Apotek Swasta Surabaya. Dalam pengambilan data peneliti banyak menggunakan metode dokumentasi dan pengajuan pertanyaan berdasarkan data objektif meliputi pengamatan penjualan obat dan alkes yang digunakan untuk menggali informasi melalui wawancara secara terperinci berdasarkan hasil penjualan periode (Januari 2017-April 2018).

Nilai trend dan hasil penjualan Januari 2017 sampai dengan April 2018 dibagi berdasarkan kuartal yang meliputi:

\section{Analisis Nilai Trend dan Hasil Penjualan Kuartal Satu Periode Januari 2017-April 2017}

Tabel 2. Hasil Penjualan Januari 2017-April 2017

\begin{tabular}{|l|l|}
\hline Bulan & Hasil Penjualan \\
\hline Januari & 278.632 .500 \\
\hline Februari & 260.687 .600 \\
\hline Maret & 281.710 .900 \\
\hline April & 278.280 .200 \\
\hline
\end{tabular}

Sumber : Hasil Penelitian, diolah (2018)

Prosentase kenaikan/penurunan penjualan perbulan sebagai berikut

Januari-Februari

$$
\begin{array}{ll}
\text { Januari-Februari } & =(260.687 .600-278.632 .500): 278.632 .500(\mathrm{X} 100 \%) \\
& =-6,4 \% \\
\text { Februari-Maret } & =(281.710 .900-260.687 .600): 260.687 .600(\mathrm{X} 100 \%) \\
& =8 \% \\
\text { Maret-April } & =(278.280 .200-281.710 .900): 281.710 .900(\mathrm{X} 100 \%) \\
& =-1,2 \%
\end{array}
$$

Maret-April

Berdasarkan data diatas, dapat disimpulkan bahwa prosentase penjualan Apotek Swasta pada kuartal satu pada bulan Februari mengalami penurunan sebesar Rp.17.944.900 atau menurun 6,4\%. Pada bulan Maret mengalami kenaikan sebesar Rp.21.023.300 atau meningkat 8\%. Pada bulan April mengalami penurunan sebesar Rp.35.207.300 atau penurunan 12,47\%. Pada bulan Maret mengalami penurunan sebesar Rp. 3.430.700 atau penurunan 1,2\%, selanjutnya akan menentukan trend dengan menggunakan metode kuadrat kecil (least square method). Berikut ini adalah kompenen least square method, dimana Y adalah data aktual dari pendapatan Apotek.

Tabel 3. Least Square Method Penjualan

\begin{tabular}{|c|c|c|c|c|}
\hline Bulan & Hasil Penjualan & $\mathbf{X}$ & $\mathbf{X}^{\mathbf{2}}$ & $\mathbf{X Y}$ \\
\hline Januari & 278.632 .500 & -3 & 9 & -835.897 .500 \\
\hline Februari & 260.687 .600 & -1 & 9 & -260.687 .600 \\
\hline Maret & 281.710 .900 & 1 & 1 & 281.710 .900 \\
\hline April & 278.280 .200 & 3 & 9 & 834.840 .600 \\
\hline Jumlah & 1.099 .311 .200 & 0 & 20 & 19.966 .400 \\
\hline
\end{tabular}

Sumber : Hasil Penelitian, diolah (2018) 


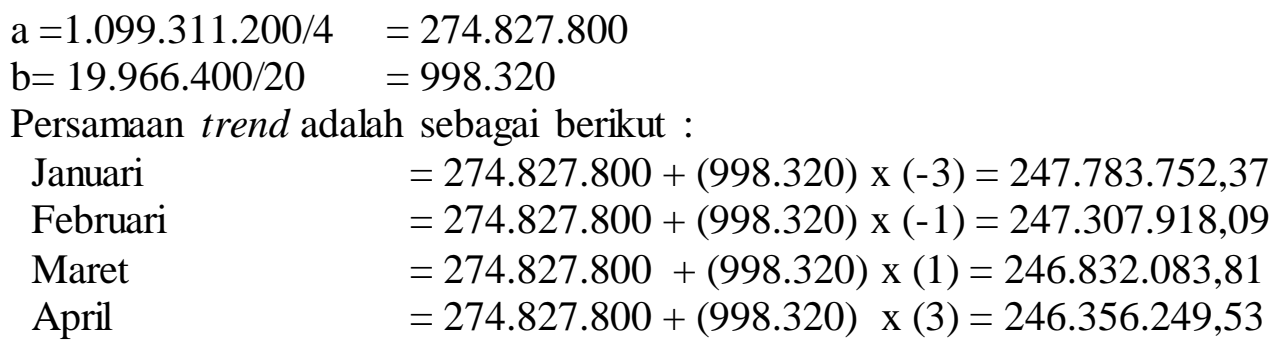

Berdasarkan analisis diatas, dapat dilihat perbedaan data aktual dari pendapatan operasional dengan data peramalan pada tabel berikut:

Tabel 4. Hasil Penjualan dan Nilai Trend

\begin{tabular}{|l|l|l|l|}
\hline Bulan & Hasil Penjualan & Trend & Varian \\
\hline Januari & 278.632 .500 & 271.832 .840 & 6.799 .660 \\
\hline Februari & 260.687 .600 & 273.829 .480 & $-13,141,880$ \\
\hline Maret & 281.710 .900 & 275.826 .120 & 5.884 .780 \\
\hline April & 278.280 .200 & 277.822 .760 & 457.440 \\
\hline
\end{tabular}

Sumber : Hasil Penelitian, diolah (2017)

Dari Tabel di atas kemudian diperjelas dengan Grafik sebagai berikut:

Gambar 1. Grafik Nilai Trend dan Hasil Penjualan Januari 2017-April 2017

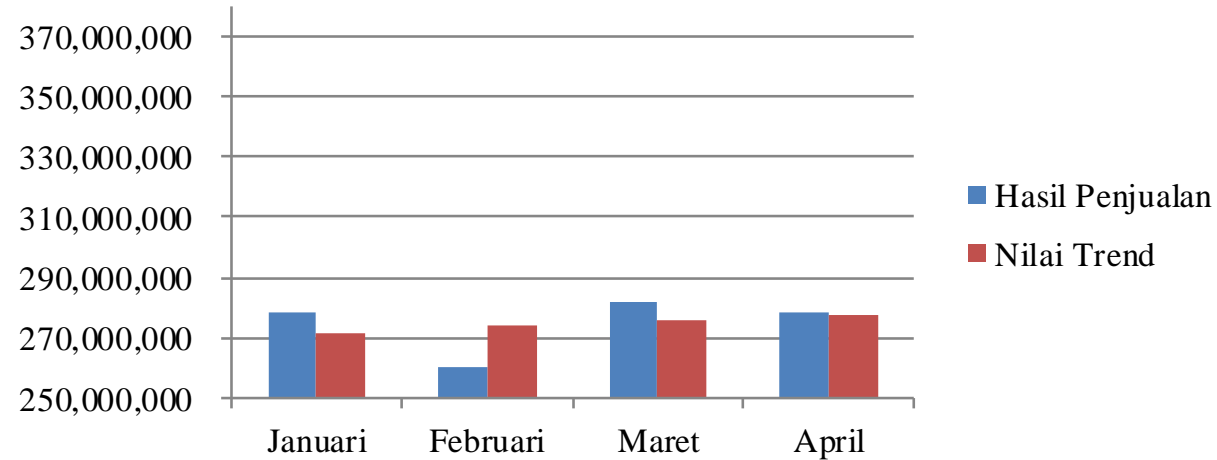

Sumber : Hasil Penelitian, diolah (2018)

Berdasarkan gambar grafik di atas, nampak jelas bahwa garis trend menunjukkan trend positif, karena garis trend dimulai dari kiri atas ke kanan atas. Berdasarkan grafik tersebut hasil penjualan ada beberapa yang tidak mencapai nilai trend.

Analisis Nilai Trend dan Hasil Penjualan Kuartal Dua Periode Mei 2017-Agustus 2017

Tabel 5. Hasil Penjualan Mei 2017-Agustus 2017

\begin{tabular}{|l|l|}
\hline Bulan & Hasil Penjualan \\
\hline Mei & 295.497 .200 \\
\hline Juni & 324.222 .500 \\
\hline Juli & 311.945 .500 \\
\hline Agustus & 313.065 .400 \\
\hline
\end{tabular}

Sumber : Hasil Penelitian, diolah (2017) 
Mei

$311.182 .650+(2.021 .380) \times(-3)=305.118 .510$

Juni

$311.182 .650+(2.021 .380) \times(-1)=309.161 .270$

Juli

$311.182 .650+(2.021 .380) \times(1)=313.204 .030$

Agustus

$311.182 .650+(2.021 .380) \times(3)=317.246 .790$

Prosentase kenaikan/penurunan penjualan perbulan sebagai berikut:

Mei-Juni

$=(324.222 .500-295.497 .200): 295.497 .200 \times(100 \%)$

$=9,7 \%$

Juni-Juli

$=(311.945 .500-324.222 .500): 324.222 .500 \times(100 \%)$

$=-3,8 \%$

Juli-Agustus

$$
\begin{aligned}
& =(313.065 .400-311.945 .500): 311.945 .500 \times(100 \%) \\
& =0,35 \%
\end{aligned}
$$

Berdasarkan data diatas, dapat disimpulkan bahwa prosentase penjualan kuartal dua Apotek Swasta pada bulan Juni mengalami kenaikan sebesar Rp. 28.725.300 atau menurun 9,7\% dari bulan Mei. Pada bulan Juli mengalami penurunan sebesar Rp. 12.277.000 atau menurun 3,8\% dari bulan Juni. Pada bulan Agustus mengalami kenaikan sebesar Rp. 1.119 .900 atau menurun 0,35\% dari bulan Juli 17. Selanjutnya akan menentukan trend dengan menggunakan metode kuadrat kecil (least square method). Berikut adalah data least square method, dimana nilai $\mathrm{Y}$ data aktual dari pendapatan Apotek.

\begin{tabular}{|c|c|c|c|c|}
\hline Bulan & Hasil Penjualan (Y) & $\mathbf{X}$ & $\mathbf{X}^{2}$ & $\mathbf{X Y}$ \\
\hline Mei & 295.497 .200 & -3 & 9 & -886.491 .600 \\
\hline Juni & 324.222 .500 & -1 & 1 & -324.222 .500 \\
\hline Juli & 311.945 .500 & -1 & 1 & 311.945 .500 \\
\hline Agustus & 313.065 .400 & 3 & 9 & 939.196 .200 \\
\hline Jumlah & 1.244 .730 .600 & 0 & 20 & 40.427 .600 \\
\hline \multicolumn{5}{|c|}{$\begin{array}{l}\text { Sumber : Hasil Penelitian, diolah (2017) } \\
=311.182 .650\end{array}$} \\
\hline
\end{tabular}

Tabel 6. Least Square Method Penjualan

Berdasarkan analisis diatas, dapat dilihat perbedaan data aktual dari pendapatan operasional dengan data peramalan pada tabel berikut:

Tabel 7. Hasil Penjualan dan Nilai Trend

\begin{tabular}{|l|l|l|l|}
\hline Bulan & Hasil Penjualan & Trend & Varian \\
\hline Mei & 295.497 .200 & 305.118 .510 & -9.612 .310 \\
\hline Juni & 324.222 .500 & 309.161 .270 & 15.061 .230 \\
\hline Juli & 311.945 .500 & 313.204 .030 & -1.258 .530 \\
\hline Agustus & 313.065 .400 & 317.246 .790 & -4.181 .390 \\
\hline
\end{tabular}

Sumber : Hasil Penelitian, diolah (2017) 
Dari tabel diatas, kemudian diperjelas dengan grafik di bawah ini:

Gambar 2. Grafik Nilai Trend dan Hasil Penjualan Mei 2017-Agustus 2017

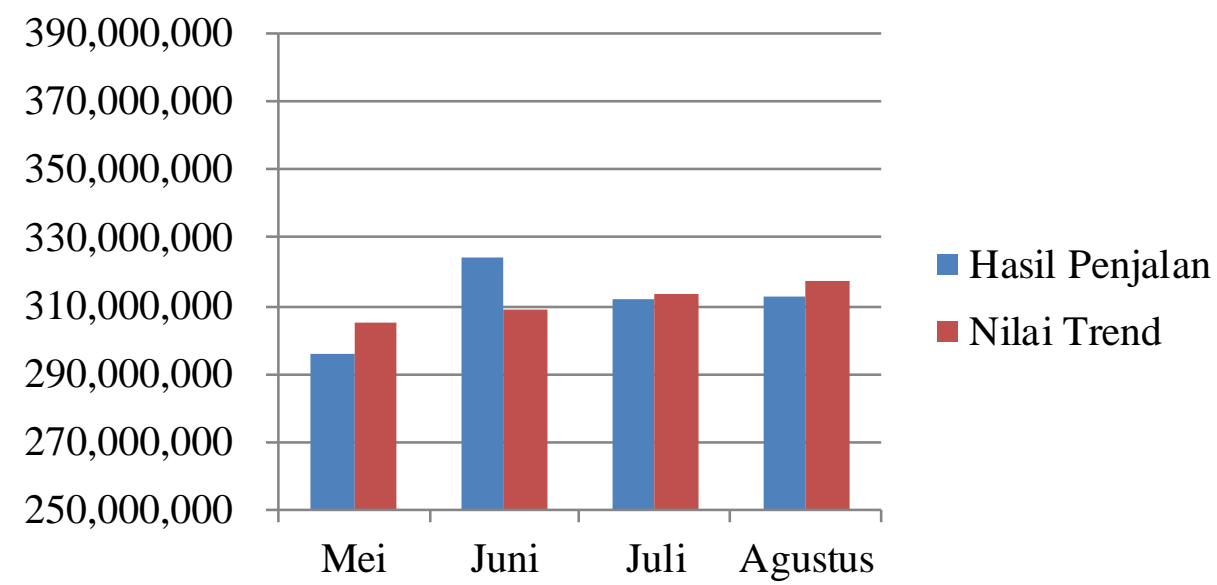

Sumber : Hasil Penelitian, diolah (2017)

Berdasarkan gambar grafik di atas, nampak jelas bahwa garis trend menunjukkan trend positif, karena garis trend dimulai dari kiri bawah ke kanan atas. Berdasarkan grafik tersebut hasil penjualan ada beberapa yang tidak mencapai nilai trend.

Analisis Nilai Trend dan Hasil Penjualan Kuartal Tiga Periode September 2017Desember 2017

Tabel 8. Hasil Penjualan September 2017-Desember 2017

\begin{tabular}{|l|l|}
\hline Bulan & Hasil Penjualan \\
\hline September & 310.855 .400 \\
\hline Oktober & 336.720 .300 \\
\hline November & 297.706 .100 \\
\hline Desember & 348.172 .100 \\
\hline
\end{tabular}

Sumber : Hasil Penelitian, diolah (2017)

Prosentase kenaikan/penurunan penjualan perbulan sebagai berikut:

September-Oktober $=(324.222 .500-295.497 .200): 295.497 .200 \times(100 \%)$ $=8,3 \%$

Oktober-November $=(311.945 .500-324.222 .500): 324.222 .500 \times(100 \%)$ $=-11,5 \%$

November-Desember

$$
\begin{aligned}
& =(313.065 .400-311.945 .500): 311.945 .500 \times(100 \%) \\
& =16,9 \%
\end{aligned}
$$

Berdasarkan data diatas, dapat disimpulkan bahwa pada kuartal Tiga penjualan obat dan alkes di Apotek Swasta pada bulan Oktober mengalami kenaikan sebesar Rp. 25.864.900 atau meningkat 8,3\% dari bulan September 2017. Pada bulan November 2017 mengalami penurunan sebesar Rp. 39.014.200 atau menurun 11,5\% dari bulan Oktober 2017. Pada bulan Desember 2017 mengalami kenaikan sebesar Rp. 50.466.000 meningkat $16,9 \%$ dari bulan November 2017. Setelah menghitung prosentasenya, selanjutnya akan menentukan trend dengan menggunakan metode kuadrat kecil (least 
square method). Berikut ini adalah data least square method, dimana Y adalah data aktual dari pendapatan Apotek.

Tabel 9. Least Square Method Penjualan

\begin{tabular}{|l|l|l|l|l|}
\hline Bulan & Hasil Penjualan (Y) & $\mathbf{X}$ & $\mathbf{X}^{\mathbf{2}}$ & $\mathbf{X Y}$ \\
\hline September & 310.855 .400 & -3 & 9 & -932.566 .200 \\
\hline Oktober & 336.720 .300 & -1 & 1 & -336.720 .300 \\
\hline November & 297.706 .100 & 1 & 1 & 297.706 .100 \\
\hline Desember & 348.172 .100 & -3 & 9 & 1.044 .516 .300 \\
\hline Jumlah & 1.293 .453 .900 & 0 & 20 & 72.935 .900 \\
\hline
\end{tabular}

Sumber : Hasil Penelitian, diolah (2017)

$\mathrm{a}=1.293 .453 .900 / 4=323.363,48$

$\mathrm{b}=167.134 .100 / 70=3.646 .795$

Persamaan trend adalah sebagai berikut:

September $\quad=323.363,48+(3.646 .795) \times(3)=312.423 .090$

Oktober $\quad=323.363,48+(3.646 .795) \times(-1)=319.716 .680$

November $\quad=323.363,48+(3.646 .795) \times(1)=327.010 .270$

Desember $\quad=323.363,48+(3.646 .795) \times(3)=334.303 .860$

Berdasarkan analisa di atas, dapat dilihat perbedaan antara data aktual dari pendapatan operasional Apotek dengan peramalannya pada tabel berikut:

Tabel 10. Hasil Penjualan dan Nilai Trend

\begin{tabular}{|l|l|l|l|}
\hline Bulan & Hasil Penjualan & Trend & Varian \\
\hline September & 310.855 .400 & 312.423 .090 & -1.567 .690 \\
\hline Oktober & 336.720 .300 & 319.716 .680 & 17.003 .620 \\
\hline November & 297.706 .100 & 327.010 .270 & -29.304 .170 \\
\hline Desember & 348.172 .100 & 334.303 .860 & 13.868 .240 \\
\hline
\end{tabular}

Sumber : Hasil Penelitian, diolah (2017)

Dari tabel diatas, kemudian diperjelas dengan grafik di bawah ini:

Gambar 3. Grafik Nilai Trend dan Hasil Penjualan

September 2017-Desember 2017

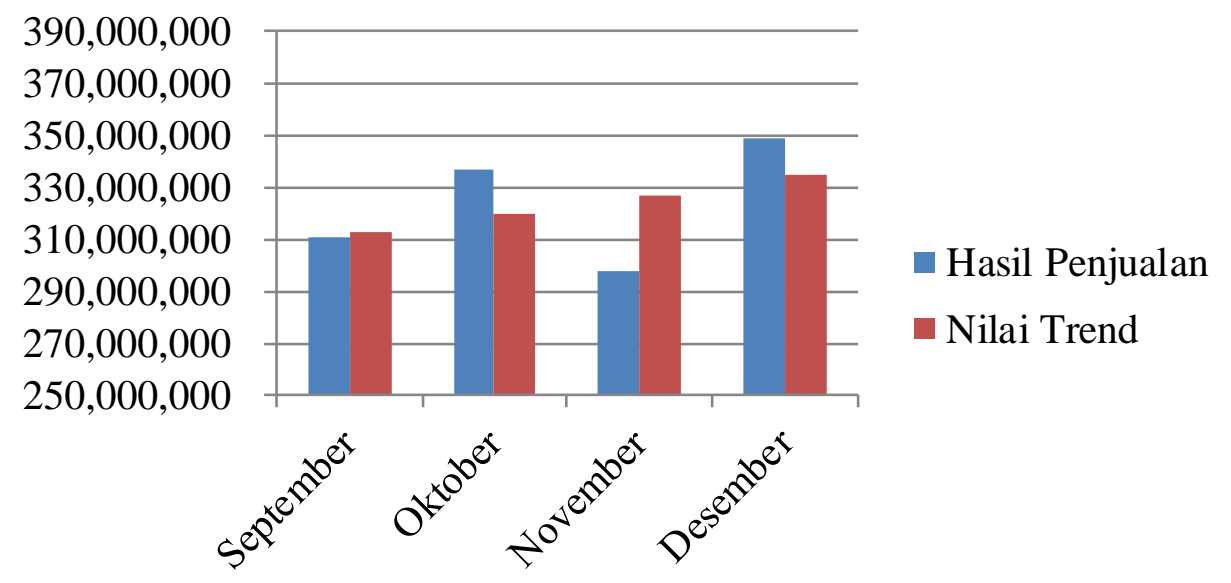

Sumber : Hasil Penelitian, diolah (2017) 
Berdasarkan gambar grafik di atas, nampak jelas bahwa garis trend menunjukkan trend positif, karena garis trend dimulai dari kiri bawah ke kanan atas. Berdasarkan grafik tersebut hasil penjualan ada beberapa yang tidak mencapai nilai trend.

Analisis Nilai Trend dan Hasil Penjualan Kuartal Empat Periode Januari 2018April 2018

Tabel 11. Hasil Penjualan Januari 2018-April 2018

\begin{tabular}{|l|l|}
\hline Bulan & Hasil Penjualan \\
\hline Januari & 337.703 .200 \\
\hline Februari & 340.557 .200 \\
\hline Maret & 381.165 .700 \\
\hline April & 350.672 .900 \\
\hline
\end{tabular}

Sumber : Hasil Penelitian, diolah (2018)

Prosentase kenaikan/penurunan penjualan perbulan sebagai berikut:

$$
\begin{array}{ll}
\text { Januari-Februari } & =(340.557 .200-337.703 .200: 337.703 .200 \times(100 \%) \\
& =0,84 \% \\
& =(381.165 .700-340.557 .200): 340.557 .200 \times(100 \%) \\
& =11,9 \% \\
\text { Mebruari-Maret } & =(350.672 .900-381.165 .700): 381.165 .700 \times(100 \%) \\
\text { Maret-April } & =-8 \%
\end{array}
$$

Berdasarkan data di atas, dapat disimpulkan pada kuartal empat penjualan di Apotek Swasta pada bulan Februari'17 mengalami mengalami kenaikan sebesar Rp. 2.854.000 atau meningkat $0,8 \%$ dari bulan Januari 2018. Pada bulan Maret 2018 mengalami kenaikan sebesar Rp. 40.608 .500 atau meningkat 11,9\% dari bulan Februari 2018. Pada bulan April 2018 mengalami penurunan sebesar Rp. 30.492 .800 atau penurunan $8 \%$ dari bulan Maret. Setelah menghitung prosentasenya selanjutnya akan menentukan trend dengan menggunakan metode kuadrat kecil (least square method). Berikut ini adalah data least square method, dimana $\mathrm{Y}$ adalah data aktual dari pendapatan Apotek.

Tabel 12. Least Square Method Penjualan

\begin{tabular}{|l|l|l|l|l|}
\hline Bulan & Hasil Penjualan & $\mathbf{X}$ & $\mathbf{X}^{\mathbf{2}}$ & $\mathbf{X Y}$ \\
\hline Januari'18 & 337.703 .200 & -3 & 9 & -1.013 .109 .600 \\
\hline Februari'18 & 340.557 .200 & -1 & 1 & -340.557 .200 \\
\hline Maret'18 & 381.165 .700 & 1 & 1 & 381.165 .700 \\
\hline April'18 & 350.672 .900 & 3 & 9 & 1.052 .018 .700 \\
\hline Jumlah & 1.410 .099 .000 & 0 & 20 & 79.517 .600 \\
\hline
\end{tabular}

$\mathrm{a}=1.410 .099 .000 / 4=352.524 .750$

$\mathrm{b}=79.517 .600 / 20=3.975 .880$ 
Persamaan trend adalah sebagai berikut :

$\begin{array}{ll}\text { Januari } & =352.524 .750+(3.975 .880) \times(-3)=340.597 .110 \\ \text { Februari } & =352.524 .750+(3.975 .880) \times(-1)=348.548 .870 \\ \text { Maret } & =352.524 .750+(3.975 .880) \times(1)=356.500 .630 \\ \text { April } & =352.524 .750+(3.975 .880) \times(3)=364.452 .390\end{array}$

Berdasarkan analisis di atas, dapat dilihat perbedaan antara data aktual dari pendapatan operasional Apotek dengan data peramalannya pada tabel berikut:

Tabel 13. Hasil Penjualan dan Nilai Trend

\begin{tabular}{|l|l|l|l|}
\hline Bulan & Hasil Penjualan & Trend & Varian \\
\hline Januari & 337.703 .200 & 340.597 .110 & -2.893 .910 \\
\hline Februari & 340.557 .200 & 348.548 .870 & -7.991 .670 \\
\hline Maret & 381.165 .700 & 356.500 .630 & 24.665 .070 \\
\hline April & 350.672 .900 & 364.452 .390 & -13.779 .490 \\
\hline
\end{tabular}

Sumber : Hasil Penelitian, diolah (2018)

Dari tabel diatas, kemudian diperjelas dengan grafik di bawah ini:

Gambar 4. Grafik Nilai Trend dan Hasil Penjualan Januari 2018-April 2018

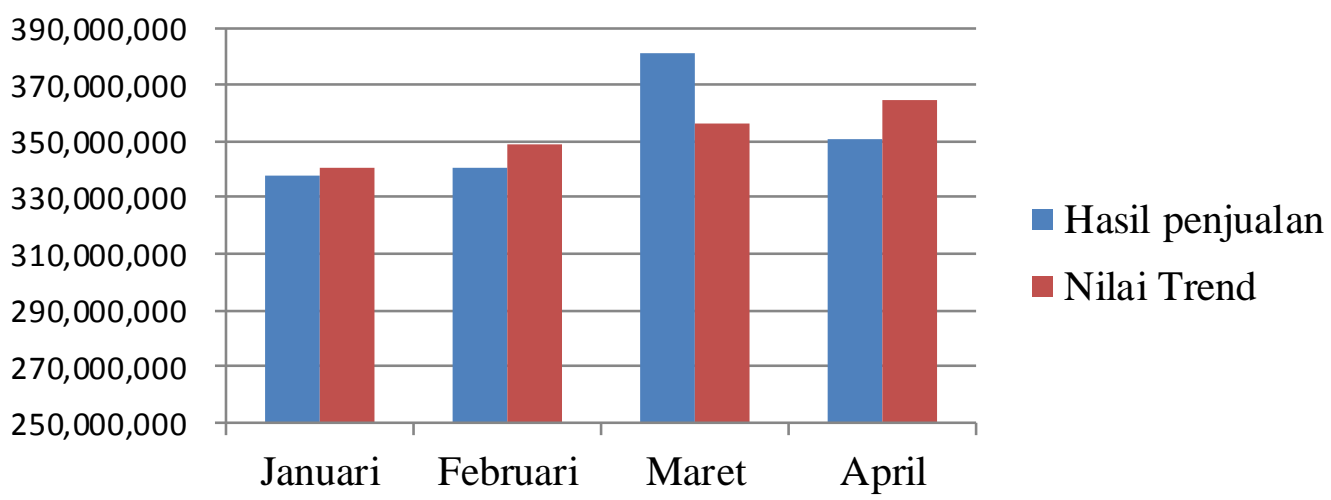

Sumber : Hasil Penelitian, diolah (2018)

Berdasarkan gambar grafik di atas, nampak jelas bahwa garis trend menunjukkan trend positif, karena garis trend dimulai dari kiri bawah ke kanan atas. Berdasarkan grafik tersebut hasil penjualan ada beberapa yang tidak mencapai nilai trend.

Berdasarkan analisis di atas, prosentase pendapatan operasional Apotek dari ke empat kuartal adalah sebagai berikut:

Tabel 14. Kuartal Hasil Penjualan

\begin{tabular}{|l|l|}
\hline Kuartal & Hasil Penjualan \\
\hline Kuartal Satu & 1.099 .311 .200 \\
\hline Kuartal Dua & 1.244 .730 .600 \\
\hline Kuartal Tiga & 1.293 .453 .900 \\
\hline Kuartal Empat & 1.410 .099 .000 \\
\hline
\end{tabular}

Sumber : Hasil Penelitian, diolah (2018)

Prosentase kenaikan/penurunan penjualan perkuartal sebagai berikut:

Kuartal Satu-Kuartal Dua $=(1.244 .730 .600-1.099 .311 .200) \quad: 1.099 .311 .200 \mathrm{x}$ $(100 \%)$ 


$\begin{aligned} & =13,2 \% \\ \text { Kuartal Dua-Kuartal Tiga } & =(1.293 .453 .900-1.244 .730 .600): 1.244 .730 .600 \mathrm{x} \\ & (100 \%) \\ & =3,9 \% \\ \text { Kuartal Tiga- Kuartal } & =(1.410 .099 .000-1.293 .453 .900): 1.293 .453 .900 \mathrm{x} \\ \text { Empat } & (100 \%) \\ & =9 \%\end{aligned}$

Berdasarkan data di atas, dapat disimpulkan penjualan di Apotek Swasta pada kuartal dua mengalami kenaikan sebesar Rp. 128.564 .900 atau meningkat 8,69\% dari kuartal satu. Pada kuartal tiga mengalami kenaikan sebesar Rp. 284.176.400 atau meningkat $17,67 \%$ dari kuartal dua. Pada kuartal empat mengalami kenaikan sebesar Rp. 163.670.900 atau meningkat 8,65\% dari kuartal tiga.

\section{Pembahasan}

Berdasarkan hasil penelitian analisis trend hasil penjualan obat dan alat kesehatan di Apotek Swasta Surabaya secara umum menunjukkan adanya peningkatan di setiap kuartalnya. Sesuai analisis hasil wawancara, pada kuartal satu faktor yang mempengaruhi penurunan hasil penjualan dari tiga narasumber dengan prosentase $100 \%$ menyatakan terjadi nilai beli rendah meskipun jumlah pengunjung mengalami peningkatan, kekosongan stok, dan pengadaan obat yang dipengaruhi oleh masyarakat sekitar karena nilai daya beli rendah. Dua narasumber dengan prosentase $66,7 \%$ menyatakan harga tidak terjangkau, terdapat keluhan harga sedikit mahal dibandingkan Apotek lain, serta terjadi kenaikan harga melebihi HET, sedangkan satu narasumber dengan prosentase $33,7 \%$ menyatakan mutu obat belum dilaksanakan sepenuhnya. Untuk meningkatkan hasil penjualan pada kuartal satu dari tiga narasumber dengan prosentase $100 \%$ menyatakan memberikan pelayanan yang ramah, edukasi mengenai informasi obat dengan tepat, memberikan fasilitas kasir berjumlah dua di bulan Januari 2017 yang memberikan efek meningkatknya hasil penjualan di kuartal satu dan seterusnya, dan sumber daya manusia yang mencukupi. Obat yang paling umum dicari pada kuartal satu diantaranya analgetik, antipireik, antidiare, persendian, dan antibiotik. Obat-obat yang mempengaruhi penjualan pada kuartal satu diantaranya Cataflam 50 mg 2.624 Tablet (Rp. 14.21.296), Incidal OD 3.806 Tablet (Rp.10.179.176), Amoxsan 500 mg 2.869 (Rp. 9.634.102), Ponstan 500 mg 3.852 Tablet (Rp.8.979.012), Amoxicillin $500 \mathrm{mg} 19.441$ (RP.7.857.614), Neuralgin 11.621 Tablet (Rp. 7.321.230), Imodium 2 mg 970 Tablet (Rp. 7.077.120), Viostin Ds 1.111 Tablet (Rp. 6.839.316), Super Tetra 6.536 Tablet (Rp. 6.401.404).

Pada kuartal dua periode Mei 2017 sampai dengan Agusus 2017 hasil garis trend menunjukkan trend positif. Bulan Mei hasil penjualan tidak mencapai nilai trend sebesar Rp. 9.612.310. Bulan Juni hasil penjualan meningkat sebesar 9,7\% dan mencapai nilai trend sebesar Rp. 15.061.230. Bulan Juli hasil penjualan menurun sebesar 3,8\% dan tidak mencapai nilai trend sebesar Rp. 1.258.530. Bulan Agustus hasil penjualan meningkat sebesar $0,35 \%$ dan tidak mencapai nilai trend sebesar Rp. 4.181.390. Berdasarkan analisa hasil wawancara kuartal dua faktor yang mempengaruhi penurunan hasil penjualan dari tiga narasumber dengan prosentase $100 \%$ menyatakan diantaranya terjadi penambahan jumlah pengunjung tetapi nilai beli 
rendah, kekosongan stok dua narasumber dengan prosentase $66,7 \%$ menyatakan terjadi keluhan mengenai harga, terjadi kenaikan harga melebihi HET dan harga obat belum terjangkau, serta satu orang berpendapat pelayanan yang ramah belum terlaksana sepenuhnya. Untuk meningkatkan hasil penjualan pada kuartal dua dari tiga narasumber dengan prosentase $100 \%$ menyatakan memberikan edukasi mengenai informasi obat dengan tepat, menjamin mutu obat, sumber daya manusia yang mencukupi dan dua narasumber dengan prosentase $66,7 \%$ pelayanan yang ramah belum terlaksana sepenuhnya.

Pada kuartal dua pada bulan juni yaitu bulan puasa dan mendekati hari raya sehingga hasil penjualan meningkat, obat yang paling umum dicari pada kuartal dua yaitu analgetik, antipiretik, antibiotik, antialergi antidiare, persendian, anti influenza. Obat-obat yang mempengaruhi penjualan pada kuartal dua diantaranya Cataflam $50 \mathrm{mg}$ 2.730 Tablet (Rp. 15.587.372), Incidal 3.832 Tablet (Rp.10.269.760), Amoxsan $500 \mathrm{mg}$ 2.744 (Rp. 9.214.352), Ponstan 500 mg 3.752 Tablet (Rp.8.745.912), Amoxicillin 500 mg 19.421 (RP.7.856.084), Imodium 2 mg 997 Tablet (Rp. 7.274. 112), Neuralgin 11.391 Tablet (Rp. 7.176.330), Mefinal 500 mg 5.057 Tablet (Rp. 6.902.805), Viostin Ds 1.091 Tablet (Rp. 6.716.196), Rhinos SR 1.221 Tablet (Rp. 6.538.455).

Pada kuartal tiga periode September 2017 sampai dengan Desember 2017 hasil garis trend menunjukkan trend positif. Bulan September hasil penjualan tidak mencapai nilai trend sebesar Rp.1.567.690. Bulan Oktober hasil penjualan meningkat sebesar 8,3\% dan tidak mencapai nilai trend sebesar Rp. 17.003.620. Bulan November hasil penjualan menurun sebesar $11,5 \%$ dan tidak mencapai nilai trend sebesar Rp. 29.304.170. Bulan Desember hasil penjualan meningkat sebesar 16,9\% dan mencapai nilai trend sebesar Rp. 13.868.240. Berdasarkan analisa hasil wawancara kuartal tiga faktor yang mempengaruhi penurunan hasil penjualan dari tiga narasumber dengan prosentase $100 \%$ menyatakan diantaranya terjadi penambahan jumlah pengunjung, tetapi nilai beli rendah, kekosongan stok, keluhan harga sedikit mahal dibandingkan Apotek lain, terjadi kenaikan harga melebihi HET, pengadaan obat yang dipengaruhi hasil penjualan dan sumber daya manusia pada kuartal ini kurang mencukupi. Satu narasumber di kuartal tiga dengan prosentase $33,7 \%$ menyatakan harga obat belum terjangkau. Untuk meningkatkan hasil penjualan pada kuartal dari 3 narasumber dengan prosentase $100 \%$ menyatakan, telah memberikan pelayanan yang ramah, edukasi mengenai informasi obat dengan tepat, menjamin mutu obat, dan mempertahankan fasilitas yang tersedia. Pada kuartal tiga terjadi perubahan musim penghujan dan obat yang paling umum dicari antihipertensi pulmonal, analgetik, antipiretik, antibiotik, antialergi, antiinfluenza, dan vitamin. Obat-obat yang mempengaruhi penjualan pada kuartal tiga diantaranya Cataflam $50 \mathrm{mg} 2.773$ Tablet (Rp. 15.878.198), Viagra 77 Tablet (Rp.10.973.923), Amoxsan 500 mg 3.185 (Rp. 10.695.230), Incidal 3.026 Tablet (Rp.8.129.920), Neuralgin 12.862 (RP.8.103.360), Imodium 2 mg 1.097 Tabet (Rp. 8.003.712), Amoxicillin $500 \mathrm{mg} 18.885$ Tablet (Rp. 7.629.540), Mefinal $500 \mathrm{mg} 5.070$ (Rp. 6.920.550), Rhinos Sr 1.288 Tablet (Rp. 6.897.240), Neurobion Forte 2.380 Tablet (Rp. 6.833.940).

Pada kuartal empat periode Januari 2018 sampai dengan April 2018 hasil garis trend menunjukkan trend positif. Bulan Januari hasil penjualan tidak mencapai nilai trend sebesar Rp.2.893.910. Bulan Februari hasil penjualan meningkat sebesar 0,84\% 
dan tidak mencapai nilai trend sebesar Rp. 7.991.670. Bulan Maret hasil penjualan meningkat sebesar 11,9\% dan mencapai nilai trend sebesar Rp. 24.665.070. Bulan April hasil penjualan menurun sebesar $8 \%$ dan tidak mencapai nilai trend sebesar Rp. 13.779.490. Berdasarkan analisa hasil wawancara kuartal empat faktor yang mempengaruhi penurunan hasil penjualan dari tiga narasumber dengan prosentase $100 \%$ menyatakan terjadi penambahan jumlah pengunjung, peningkatan nilai beli, kekosongan stok, terjadi kenaikan, keluhan harga lebih mahal dibandingkan Apotek lain, dan sumber daya manusia pada kuartal ini kurang mencukupi. Pelayanan yang ramah, menjamin mutu obat, harga terjangkau belum terlaksana sepenuhnya dari dengan prosentase $66,7 \%$. Untuk meningkatkan hasil penjualan pada kuartal empat dari tiga narasumber dengan prosentase $100 \%$ menyatakan, telah memberikan edukasi mengenai informasi obat dengan tepat, fasilitas yang dipertahankan, pengadaan obat yang tidak lagi dipengaruhi oleh hasil penjualan. Pada kuartal empat obat yang paling sering dicari yaitu antibiotik, vitamin, antialergi, analgetik, antipiretik, antidiare, herbal, tetes mata, dan pil KB. Obat-obat yang mempengaruhi penjualan diantaranya Cataflam 50 mg 2.747 Tablet (Rp. 15.729.322), Rhinos Tablet (Rp.10.525.322), Amoxsan 500 mg 3.078 (Rp.10.393.062), Incidal OD 3.717 (Rp.10.178.268), Mefinal 500 mg 5.607 Tablet (Rp. 7.707.726) Neuralgin 12.880 (RP.8.768.420), Imodium 2 mg 1.037 (Rp. 7.565.952), Soman 37 (Rp. 7.231.465), Diane 69 Pcs (Rp. 7.112.225), Cendo Xitrol 5 $\mathrm{ml} 258$ Pcs (Rp. 7.733.550).

\section{KESIMPULAN DAN SARAN Kesimpulan}

Pada penelitian analisis trend hasil penjualan obat dan alkes di Apotek Swasta mengalami peningkatan setiap kuartalnya. Pada kuartal dua hasil penjualan meningkat sebesar 8,69\% dari kuartal satu. Pada kuartal tiga hasil penjualan meningkat sebesar $17,67 \%$ dari kuartal dua. Pada kuartal empat hasil penjualan meningkat sebesar $8,65 \%$ tidak setinggi kuartal tiga.

Faktor-faktor yang mempengaruhi hasil penjualan diantaranya yaitu penambahan dan penurunan jumlah pasien, terjadinya kekosongan stok obat, keluhan pasien, pelayanan yang diberikan kepada pasien, pengadaan obat yang dipengaruhi masyarakat sekitar, fasilitas yang dapat meningkatkan penjualan, ketersediaan tenaga kerja sesuai kebutuhan Apotek, dan harga yang bersaing.

\section{Saran}

1. Pada penelitian ini dilakukan pengamatan berdasarkan faktor-faktor intern untuk peneliti selanjutnya dapat ditambahkan faktor ekstern penjualan obat dan alat kesehatan.

2. Pada penelitian ini dilakukan pengamatan berdasarkan data penjualan tahun sebelumnya dengan melihat kenaikan, penurunan, serta nilai trend untuk penelitian selanjutnya dapat ditambahkan peramalan penjualan peramalan tahun yang akan datang.

3. Apotek Swasta Surabaya diharapkan mulai memperhatikan faktor-faktor yang dapat mempengaruhi penurunan atau kenaikan hasil penjualan seperti harga yang lebih 
mahal, menyediakan kotak kritik saran, meningkatkan up-selling dengan memperhatikan jumlah karyawan serta dapat melakukan konseling ke Pasien.

\section{DAFTAR PUSTAKA}

Budiasih, Yanti. 2012. Statistik Deskriptif untuk Ekonomi dan Bisnis. Tangerang: Jelajah Nusa.

Harahap, Sofyan Safri. 2009. Analisis Kritis Atas Laporan Keuangan. Jakarta: PT. Rajagrafindo Persada.

Munandar, M. 2010. Budgeting Perencanaan Kerja Pengkoordinasian Kerja Pengawasan Kerja. Yogyakarta: BPFE.

Peraturan Menteri Kesehatan Republik Indonesia. Nomor 1190/Menkes/Per/VIII/2010. 2010. Penyaluran Alat Kesehatan. Jakarta: Menteri Kesehatan.

Peraturan Menteri Kesehatan Republik Indonesia. Nomor 98 Tahun 2015. 2015. Tentang Pemberian Informasi Harga Eceran Tertinggi Obat. Jakarta: Menteri Kesehatan.

Republik Indonesia. Undang-Undang Nomor 36 Tahun 2009. Tentang Kesehatan 2009.

Seto, S., Nita, Y., \& Triana, L. 2009. Manajemen Farmasi. Surabaya: Airlangga University Press. 